DOI https://doi.org/10.30525/978-9934-26-007-0-14

\title{
КРИМІНАЛЬНО-ПРАВОВА ХАРАКТЕРИСТИКА ПРЕДМЕТА НЕЗАКОННОГО ЗБАГАЧЕННЯ
}

\section{Кришевич О. В., Безгинський Б. Г.}

\section{ВСТУП}

У кримінально-правовій науці велике значення має правильне теоретичне та практичне розуміння предмета складу кримінального правопорушення, оскільки вміння чітко виокремити у кримінально-правовій нормі предмет сприятиме належній кваліфікації кримінального правопорушення. На сучасному етапі розвитку правової діяльності держави одним із пріоритетних питань залишається протидія корупційним правопорушенням, учинених службовими особами. Одним із видів корупційних кримінальних правопорушень $\epsilon$ незаконне збагачення. Кримінальна відповідальність передбачена ст. 368-5 Кримінального кодексу України (далі - КК), у якій зазначено, що незаконне збагачення - набуття особою, уповноваженою на виконання функцій держави або місцевого самоврядування, активів, вартість яких більше ніж на шість тисяч п'ятсот неоподатковуваних мінімумів доходів громадян перевищує її законні доходи. Предметом складу кримінального правопорушення, передбаченого ст. 368-5 КК, є активи, під якими, згідно із ч. 3 ст. 368-5 КК, варто розуміти грошові кошти (зокрема, готівкові кошти, кошти, що перебувають на банківських рахунках чи на зберіганні в банках або інших фінансових установах), інше майно, майнові права, нематеріальні активи, зокрема і криптовалюти, обсяг зменшення фінансових зобов'язань, а також роботи чи послуги, надані особі, уповноваженій на виконання функцій держави або місцевого самоврядування ${ }^{1}$. Предмет незаконного збагачення належить до предметів кримінальних правопорушень у сфері службової діяльності та професійної діяльності, пов'язаної з наданням публічних послуг. Активи, які перелічені у кримінально-правовій нормі щодо незаконного збагачення, використовуються та застосовуються в різних нормативних документах, що зумовлює проблематику й актуальність їх дослідження.

\footnotetext{
${ }^{1}$ Кримінальний кодекс України від 5 квітня 2001 p., документ 2341-III. URL: https://zakon.rada.gov.ua/laws/show/2341-14.
} 


\section{1. Грошові кошти як предмет незаконного збагачення}

Першою складовою частиною активів предмета незаконного збагачення $\epsilon$ грошові кошти. Під час проведення аналізу низки нормативноправових актів ми звернули увагу на те, що термін «грошові кошти» не $\epsilon$ уніфікованим та тлумачиться по-різному. Відповідно до ст. 192 Цивільного кодексу України (далі - ЦК), законним платіжним засобом, обов'язковим до приймання за номінальною вартістю на всій території України, є грошова одиниця України - гривня. Іноземна валюта може використовуватися в Україні у випадках і в порядку, встановлених законом². Поняття «грошові кошти» передбачене в абз. 6 п. 4 розд. I Національного положення (стандарт) бухгалтерського обліку в державному секторі 101 «Подання фінансової звітності», затвердженого наказом Міністерством фінансів України від 28 грудня 2009 р. № 1541, відповідно до якого грошові кошти готівка, кошти на рахунках в органах Державної казначейської служби України (далі - органи Казначейства), у банках та депозити до запитання ${ }^{3}$. У п. 6 Міжнародного стандарту бухгалтерського обліку 7 (далі - МСБО 7) «Звіт про рух грошових коштів» передбачено, що грошові кошти складаються з готівки в касі і депозитів до запитання. Еквіваленти грошових коштів - це короткострокові високоліквідні інвестиції, які вільно конвертуються у відомі суми грошових коштів і яким притаманний незначний ризик зміни вартості ${ }^{4}$.

Закон України «Про платіжні системи та переказ коштів в Україні» цілком заміняе поняття «грошові кошти» терміном «кошти». У ст. 3 зазначеного Закону передбачено, що кошти існують у готівковій формі (форма грошових знаків) або в безготівковій формі (форма записів на рахунках у банках). Грошові знаки випускаються у формі банкнот і монет, що мають зазначену на них номінальну вартість. Гривня як грошова одиниця України є єдиним законним платіжним засобом в Україні, приймається всіма фізичними $\mathrm{i}$ юридичними особами без будь-яких обмежень на всій території України для проведення переказів та розрахунків ${ }^{5}$. Окрім цього, відповідно до п. 3 Положення про ведення касових операцій у національній валюті в Україні, затвердженого постановою правління Національного банку України від 29 грудня 2017 р. № 148, готівка - грошові знаки національної валюти

\footnotetext{
${ }^{2}$ Цивільний кодекс України від 16 січня 2003 р., документ 435-IV. URL: https://zakon.rada.gov.ua/ laws/show/435-15.

3 Про затвердження Національного положення (стандарту) бухгалтерського обліку в державному секторі 101 «Подання фінансової звітності» : наказ Міністерства фінансів України від 28 грудня 2009 р. № 1541, документ z0103-10. URL: https://zakon.rada.gov.ua/laws/show/z0103-10\#Text.

${ }^{4}$ Міжнародний стандарт бухгалтерського обліку 7 (МСБО 7). Звіт про рух грошових коштів від 1 січня 2012 р., документ 929_019. URL: https://zakon.rada.gov.ua/laws/show/929_019\#Text.

5 Про платіжні системи та переказ коштів в Україні : Закон України від 12 червня 2001 р. № 2658-III. URL: https://zakon.rada.gov.ua/laws/show/2658-14\#Text.
} 
України (банкноти і монети, зокрема, розмінні, обігові, пам'ятні монети, які є платіжними засобами); готівкова виручка (готівка) - сума фактично одержаної готівки від реалізації продукції (товарів, робіт, послуг), а також від операцій, що безпосередньо не пов'язані з реалізацією продукції (товарів, робіт, послуг) та іншого майна ${ }^{6}$.

Розглянемо поняття «грошові кошти» 3 економічного погляду. М.В. Срмолаєва, А.М. Гафіяк та К.В. Чернеченко звертають увагу на те, що в економічній літературі виділяють поняття «гроші» як загальноекономічну категорію і «грошові кошти» як суто бухгалтерську категорію7. Поняття «грошові кошти» у своїй науковій праці досліджувала К.І. Мага, яка зазначала, що грошові кошти є вираженням вартості всіх товарів, як вид універсального товару, який $є$ загальним еквівалентом. Грошові кошти виступають у формі готівки в касі, коштів на рахунках у банку, депозитів до запитання, коштів й дорозі й електронних грошей, що відображають активи підприємства ${ }^{8}$. Д.І. Коваленко вважає, що гроші мають товарну форму та характеризують обмін у товарній економіці ${ }^{9}$. Погоджуємося із тлумаченням Л.М. Рябініної, яка зазначає, що гроші - кредитний знак ціни, виконують такі функції: засобу обігу, засобу вираження товарних цін, засобу платежу i, за умови їхньої сталості, засобу збереження і нагромадження цінності ${ }^{10}$. Вищезазначені визначення відображають переважно природу та значення грошей. Незважаючи на численні економічні визначення, підгрунтям для визначення предмета кримінального правопорушення під час кваліфікації діяння особи $є$ юридичне (законодавче) визначення. Ми погоджуємося з думкою О.С. Бондаренко, яка зазначає, що грошима у складі неправомірної вигоди $\epsilon$ монети, паперові гроші, електронні гроші, кредитні гроші та валютні цінності ${ }^{11}$. Розглянемо кожну 3 перелічених форм грошей окремо.

До готівкових грошей належать монети та паперові гроші. Відповідно до пп. 11 та пп. 12 п. 1 Правил визначення платіжних ознак та обміну банкнот, розмінних та обігових монет національної валюти України, затверджених постановою правління Національного банку України від

\footnotetext{
${ }^{6}$ Про затвердження Положення про ведення касових операцій у національній валюті в Україні : постанова правління Національного банку України від 29 грудня 2017 р. № 148, документ v0148500-17. URL: https://zakon.rada.gov.ua/laws/show/v0148500-17\#Text.

${ }^{7}$ Єрмолаєва М.В., Черненко К.В., Гафіяк А.М. Облік грошових коштів та застосування інформаційних облікових технологій. 2013. С. 216.

${ }^{8}$ Мага К.І. Поняття «грошові кошти та їх еквіваленти» і його відображення в обліково-аналітичній системі підприємства. 2018. С. 108.

${ }^{9}$ Коваленко Д.І. Гроші та кредит : теорія і практика : навчальний посібник. Київ, 2011. С. 344 .

${ }^{10}$ Рябіна Л.М. Функції сучасних грошей та їх особливості. Вісник соиіально-економічних досліджень. 2011. C. 99.

${ }^{11}$ Бондаренко О.С. Предмет злочинів у сфері службової діяльності та професійної діяльності, пов'язаної з наданням публічних послуг. Київ, 2016. С. 90.
} 
3 грудня 2018 р. № 134, справжні банкноти - уведені в обіг Національним банком як законний засіб платежу паперові грошові знаки, що мають установлені розміри, дизайн, елементи захисту та на яких зазначені реквізити (номінал, рік виготовлення, серійний номер); справжні розмінні й обігові монети - уведені в обіг Національним банком як законний засіб платежу металеві грошові знаки, що мають установлені форму, технічні характеристики, розміри, у яких розрізняють аверс, реверс, на яких зображені малий Державний Герб України, номінал, найменування держави, логотип Банкнотно-монетного двору Національного банку України, рік виготовлення й обріз (гурт) $)^{12}$.

Наступною формою грошей є електронні гроші. Відповідно до ст. 15 Закону України «Про платіжні системи та переказ коштів в Україні», електронні гроші- одиниці вартості, які зберігаються на електронному пристрої, приймаються як засіб платежу іншими особами, ніж особа, яка їх випускає, i $\epsilon$ грошовим зобов'язанням цієї особи, що виконується в готівковій або безготівковій формі. Випуск електронних грошей може здійснювати виключно банк. Банк, що здійснює випуск електронних грошей, бере на себе зобов'язання 3 їх погашення ${ }^{13}$. На нашу думку, порівняно 3 готівковими грошима, електронні гроші мають деякі переваги та недоліки. Серед позитивних моментів виокремлюємо: швидкий та зручний формат розрахунку, можливість переказу грошової суми з однієї країни в іншу, більшість систем, на яких зберігаються електронні гроші, нараховують відсотки їхнім власникам.

Серед недоліків варто виокремити: зберігання грошей власників гаманців на рахунках юридичних осіб, зняття готівки відбувається 3 комісією, електронні гроші стають найбільш зручним предметом для вчинення корупційних кримінальних правопорушень та шахрайства стосовно їхніх власників.

Різновидами кредитних грошей є векселі та чеки. Відповідно до ст. 14 Закону України «Про цінні папери та фондовий ринок», вексель - цінний папір, який посвідчує безумовне грошове зобов'язання векселедавця або його наказ третій особі сплатити після настання строку платежу визначену суму власнику векселя (векселедержатель). Векселі можуть бути прості або переказні, що існують виключно у документарній формі ${ }^{14}$. Основною відмінністю між ними є особа, яка має право їх видавати (простий вексель

\footnotetext{
12 Про затвердження Правил визначення платіжних ознак та обміну банкнот, розмінних та обігових монет національної валюти України : постанова правління Національного банку України від 3 грудня 2018 р. № 134, документ v0134500-18. URL: https://zakon.rada.gov.ua/laws/show/v0134500-18\#Text.

13 Про платіжні системи та переказ коштів в Україні : Закон України від 12 червня 2001 р. № 2658-III. URL: https://zakon.rada.gov.ua/laws/show/2658-14\#Text.

${ }^{14}$ Про цінні папери та фондовий ринок : Закон України від 23 лютого 2006 р. № 3480-IV. URL: https://zakon.rada.gov.ua/laws/show/3480-15\#Text.
} 
видається боржником, а переказний - позичальником). Визначення чека закріплено в п. 1.6 Положення про порядок здійснення операцій із чеками в іноземній валюті на території України, затвердженого постановою правління Національного банку України від 29 грудня 2000 р. № 520, у якому зазначено, що чек - паперовий розрахунковий документ установленої форми, що містить нічим не обумовлене письмове розпорядження чекодавця платнику про сплату чекодержателю зазначеної в ньому суми коштів протягом установленого строку. Розрізняють іменні чеки та чеки на пред'явника. Іменний чек містить вказівку на особу, якій мають бути виплачені гроші, натомість чек на пред'явника такої вказівки не має, тому одержати грошові кошти має право будь-яка особа, яка пред’являє такий чек ${ }^{15}$. Наступною формою грошей $\epsilon$ валютні цінності. Відповідно до ч. 1 ст. 1 Закону України «Про валюту і валютні цінності», валютні цінності національна валюта (гривня), іноземна валюта та банківські метали. Національна валюта (гривня): грошові знаки грошової одиниці України гривні у вигляді банкнот, монет, зокрема й обігових, пам'ятних та ювілейних монет, i в інших формах, що перебувають в обігу та $\epsilon$ законним платіжним засобом на території України, а також вилучені або такі, що вилучаються з обігу, але підлягають обміну на грошові знаки, що перебувають в обігу; кошти на рахунках у банках та інших фінансових установах, виражені у гривні; електронні гроші, номіновані у гривні. Іноземна валюта - грошові знаки грошових одиниць іноземних держав у вигляді банкнот, казначейських білетів, монет, що перебувають в обігу та є законним платіжним засобом на території відповідної іноземної держави або групи іноземних держав, а також вилучені або такі, що вилучаються з обігу, але підлягають обміну на грошові знаки, що перебувають в обігу; кошти на рахунках у банках та інших фінансових установах, виражені угрошових одиницях іноземних держав i міжнародних розрахункових (клірингових) одиницях (зокрема, у спеціальних правах запозичення), що належать до виплати в іноземній валюті; електронні гроші, номіновані у грошових одиницях іноземних держав та (або) банківських металах ${ }^{16}$. Визначення терміна «банківські метали» передбачене в п. 13 ст. 1 Закону України «Про державне регулювання видобутку, виробництва і використання дорогоцінних металів і дорогоцінного каміння та контроль за операціями з ними», де зазначено, що банківські метали - це золото, срібло, платина, метали платинової групи, доведені (афіновані) до

\footnotetext{
${ }^{15}$ Про затвердження Положення про порядок здійснення операцій із чеками в іноземній валюті на території України : постанова правління Національного банку України від 29 грудня 2000 р. № 520 , документ z0152-01. URL: https://zakon.rada.gov.ua/laws/show/z0152-01\#Text.

${ }^{16}$ Про валюту і валютні цінності : Закон України від 21 червня 2018 р. № 2473-VIII. URL: https://zakon.rada.gov.ua/laws/show/2473-19\#Text.
} 
найвищих проб у зливках і порошках, що мають сертифікат якості, а також монети, вироблені з дорогоцінних металів ${ }^{17}$.

\section{2. Інше майно, майнові права та нематеріальні активи як предмет незаконного збагачення}

Однією зі складових частин активів, що $є$ предметом незаконного збагачення, є інше майно. Відповідно до ст. 190 ЦК України, майном як особливим об'єктом уважаються окрема річ, сукупність речей, а також майнові права й обов'язки. Майнові права $є$ неспоживною річчю. Майнові права визнаються речовими правами ${ }^{18}$. У ст. 139 Господарського кодексу України передбачено, що майном визнається сукупність речей та інших цінностей (зокрема, нематеріальні активи), які мають вартісне визначення, виробляються чи використовуються в діяльності суб'єктів господарювання та відображаються в їхньому балансі або враховуються в інших передбачених законом формах обліку майна цих суб'єктів ${ }^{19}$. Визначення терміна «майно» також передбачене в п. d) ст. 2 Конвенція Організації Об'єднаних Націй проти корупції, де зазначено, що майно - будь-які активи, матеріальні або нематеріальні, рухомі або нерухомі, виражені в речах або у правах, а також юридичні документи або активи, що підтверджують право власності на такі активи або інтерес у них ${ }^{20} .3$ викладеного випливає, що першим компонентом поняття «майно» $є$ речі. Відповідно до ст. ст. 179 та 181 ЦК України, річчю є предмет матеріального світу, щодо якого можуть виникати цивільні права й обов'язки. Речі поділяються на рухомі та нерухомі. До нерухомих речей (нерухоме майно, нерухомість) належать земельні ділянки, а також об'єкти, розташовані на земельній ділянці, переміщення яких $є$ неможливим без їхнього знецінення та зміни їхнього призначення. Режим нерухомої речі може бути поширений законом на повітряні та морські судна, судна внутрішнього плавання, космічні об'єкти, а також інші речі, права на які підлягають державній реєстрації. Рухомими речами є речі, які можна вільно переміщувати у просторі ${ }^{21}$. Наступною складовою частиною поняття «майно»є майнові права. Відповідно до абз. 3

\footnotetext{
${ }^{17}$ Про державне регулювання видобутку, виробництва і використання дорогоцінних металів i дорогоцінного каміння та контроль за операціями з ними : Закон України від 18 листопада 1997 р. № 637/97-BP. URL: https://zakon.rada.gov.ua/laws/show/637/97-\%D0\%B2\%D1\%80\#Text.

18 Цивільний кодекс України : Закон від 16 січня 2003 p. № 435-IV. URL: https://zakon.rada.gov.ua/ laws/show/435-15.

${ }^{19}$ Господарський кодекс України : Закон від 16 січня 2003 р. № 436-IV. URL: https://zakon.rada.gov.ua/ laws/show/436-15\#Text.

${ }^{20}$ Конвенція Організації Об'єднаних Націй проти корупції від 31 жовтня 2003 р., документ 995-с16. URL: https://zakon.rada.gov.ua/laws/show/995-c16\#Text.

21 Цивільний кодекс України : Закон від 16 січня 2003 р. № 435-IV. URL: https://zakon.rada.gov.ua/ laws/show/435-15.
} 
ч. 2 ст. 3 Закону України «Про оцінку майна, майнових прав та професійну оціночну діяльність в Україні», майновими правами, які можуть оцінюватися, визнаються будь-які права, пов'язані з майном, відмінні від права власності, зокрема й права, які є складовими частинами права власності (права володіння, розпорядження, користування), а також інші специфічні права (права на провадження діяльності, використання природних ресурсів тощо) та права вимоги ${ }^{22}$. У зв'язку із взаємозалежністю майнові обов'язки можуть бути предметом кримінального правопорушення лише в комплексі 3 майновими правами.

Різновидом майна як предмета складу кримінального правопорушення незаконного збагачення $є$ активи. С.А. Чернецька зазначає, що активи - це все, чим володіє підприємство (готівка, дебіторська заборгованість, обладнання та майно підприємства) ${ }^{23}$. Є три види активів: 1) оборотні активи - готівка та кошти, запаси, які можуть бути досить швидко трансформовані в готівку (зазвичай протягом року); 2) основні фонди з довгим терміном служби, що використовуються підприємством під час виробництва товарів і послуг (наприклад, будівлі, споруди, земля, обладнання); 3) інші активи, які включають такі нематеріальні активи, як патенти і торгові знаки (що не мають натурально-речової форми, але цінні для підприємства), капіталовкладення в інші компанії або довготермінові цінні папери, «витрати майбутніх періодів» і різні інші активи (залежно від профілю того чи іншого підприємства). Відповідно до п. 12 Міжнародного стандарту бухгалтерського обліку 38 (далі - МСБО 38) «Нематеріальні активи», актив $\epsilon$ ідентифікованим, якщо він: а) може бути відокремлений, тобто його можна відокремити або відділити від суб'єкта господарювання і продати, передати, ліцензувати, здати в оренду або обміняти індивідуально або разом із пов'язаним із ним контрактом, ідентифікованим активом чи зобов'язанням, незалежно від того, чи має суб'єкт господарювання намір зробити це; б) виникає внаслідок договірних або інших юридичних прав незалежно від того, чи можуть вони бути передані або відокремлені від суб'єкта господарювання або ж від інших прав та зобов'язань ${ }^{24}$. Визначені три основні властивості активу, як-от: власність (активи являють собою право власності, яке зрештою може бути перетворено на грошові кошти та їхні еквіваленти), економічна цінність (активи мають економічну цінність i можуть бути обмінені або продані), ресурс (активи - це ресурси, які можна використовувати для отримання майбутніх економічних вигод). Визначення

\footnotetext{
${ }^{22}$ Про оцінку майна, майнових прав та професійну оціночну діяльність в Україні : Закон України від 5 квітня 2001 р. № 2346-III. URL: https://zakon.rada.gov.ua/laws/show/2658-14\#Text.

${ }^{23}$ Чернецька С.А. Аналіз активів підприємств. Облік, аналіз, аудит. 2013. С. 332.

24 Міжнародний стандарт бухгалтерського обліку 38 (МСБО 38) «Нематеріальні активи» від 1 січня 2012 р., документ № 929-050. URL: https://zakon.rada.gov.ua/laws/show/929_050.
} 
поняття «нематеріальні активи» наведене в п. 4 розд. I та п. 1 розд. II Національного положення (стандарт) бухгалтерського обліку в державному секторі «Нематеріальні активи», затвердженого наказом Міністерства фінансів України від 12 жовтня 2010 р. № 1202, у якому зазначено, що нематеріальний актив - немонетарний актив, який не має матеріальної форми та може бути ідентифікований. Нематеріальний актив визнається активом, якщо його можна ідентифікувати (може бути виділений чи відокремлений від інших активів) та існує ймовірність отримання суб'єктом державного сектора майбутніх економічних вигід, пов'язаних із його використанням, та/або якщо він має потенціал корисності і його вартість може бути достовірно визначена. Зазначене положення роз'яснює поняття «немонетарний актив», у якому закріплено, що немонетарні активи - усі активи, крім грошових коштів, їхніх еквівалентів та дебіторської заборгованості у фіксованій (або визначеній) сумі грошей ${ }^{25}$.

Розглянемо класифікацію нематеріальних активів. О.С. Бондаренко пропонує класифікувати нематеріальні активи залежно від того, із яким правом (право інтелектуальної власності чи право власності) вони пов'язані. Перший вид об’єднує нематеріальні активи, що $є$ результатами інтелектуальної діяльності: об'єкти авторського права, об'єкти суміжного права, об'єкти промислової власності, інші права. Другий вид об'єднує нематеріальні активи, що є проявами реалізації однієї із правомочностей права власності, а саме права користування ${ }^{26}$.

Одним із видів нематеріальних активів, який складно віднести до жодної 3 вищезазначених груп, є гудвіл. Відповідно до ст. 14.1.40. Податкового кодексу України, гудвіл (вартість ділової репутації) - нематеріальний актив, вартість якого визначається як різниця між ринковою ціною та балансовою вартістю активів підприємства як цілісного майнового комплексу, що виникає в результаті використання кращих управлінських якостей, панівної позиції на ринку товарів, послуг, нових технологій тощо. Вартість гудвілу не підлягає амортизації і не враховується під час визначення витрат платника податку, щодо активів якого виник такий гудві ${ }^{27}$. Гудвіл становить певний інтерес як для керівництва підприємства, так і для зацікавлених зовнішніх користувачів, що прагнуть узяти участь в інвестуванні, оскільки оцінка гудвілу $є$ оцінкою минулих і майбутніх

\footnotetext{
${ }^{25}$ Про Національне положення (стандарт) бухгалтерського обліку в державному секторі 122 «Нематеріальні активи»: наказ Міністерства фінансів України від 12 жовтня 2010 р. № 1202. URL: https://zakon.rada.gov.ua/laws/show/z1018-10\#Text.

${ }^{26}$ Бондаренко О.С. Предмет злочинів у сфері службової діяльності та професійної діяльності, пов'язаної з наданням публічних послуг. Київ, 2016. С. 90.

${ }^{27}$ Податковий кодекс України : Закон від 2 грудня 2010 р. № 2755-VI ; ред. станом на 21 жовтня 2020 р. Відомості Верховної Ради Украӥни. 2011. № № 13-17. Ст. 112. URL: https://zakon.rada.gov.ua/laws/ show/2755-17.
} 
доходів підприємства, його потенціалу. Згідно зі стандартами BVS-I, ухваленими в 1988 р. і доповненими в 1991 р. Американським товариством оцінювачів (American Society of Appraisers, ASA), гудвіл визначається як «добре ім'я» і включає нематеріальні активи компанії, які складаються із престижу підприємства, його ділової репутації, відносин із клієнтами, місцезнаходження, номенклатури продукції, що випускається тощо. Ці чинники спеціально не виділяються і не враховуються у звітності підприємств, але $є$ реальним джерелом прибутку. Поняття «гудвіл» охоплює такі види нематеріальних активів підприємства, як: торгові марки; заголовки та назви видань; комп'ютерне програмне забезпечення; ліцензії та привілеї; авторські права, патенти й інші права інтелектуальної власності, права на обслуговування й експлуатацію; рецепти, формули, моделі, проєкти та прототипи; нематеріальні активи на етапі розроблення тощо. Вартість гудвілу не підлягає амортизації та не враховується під час визначення витрат платника податку, щодо активів якого виник такий гудвіл. Гудвіл - перевищення вартості придбання над часткою покупця у справедливій вартості придбаних ідентифікованих активів, зобов'язань і непередбачених зобов'язань на дату придбання. Гудвіл виникає під час придбання, злиття підприємств, а також висвітлення інформації про об'єднання підприємств. Відповідно до ст. 2 Закону України «Про банки і банківську діяльність», ділова репутація - відомості, зібрані Національним банком України, про відповідність діяльності юридичної або фізичної особи, зокрема й керівників юридичної особи та власників істотної участі в такій юридичній особі, вимогам закону, діловій практиці та професійній етиці, а також відомості про порядність, професійні й управлінські здібності фізичної особи ${ }^{28}$. Відмежування понять «ділова репутація» та «гудвіл» досліджувала О.В. Кришевич. Ділову репутацію, що є особистим немайновим благом, трактують як усталену оцінку фізичної особи, що грунтується на наявній інформації про іiї позитивні та негативні суспільно значущі діяння (поведінка) у певній сфері (професійна, підприємницька, службова тощо). Це суспільна думка про особу з погляду моралі певного суспільства чи соціальної групи. У такій інтерпретації поняття ділової репутації наближається до поняття гідності та честі (ст. 297 ЦК України), що $€$ підставою для ототожнення цих понять. Чи не єдина суттєва відмінність між ними полягає в тому, що честю (як і гідністю) наділена тільки фізична особа, а ділова репутація - особисте немайнове благо, притаманне як фізичним, так і юридичним особам (суб'єкти господарювання). Гудвіл - це грошова оцінка, тобто вартість ділової репутації.

\footnotetext{
${ }^{28}$ Про банки і банківську діяльність : Закон України від 7 грудня 2000 p. № 2121-III. URL: https://zakon.rada.gov.ua/laws/show/2121-14\#Text.
} 
У великих компаній гудвіл $\epsilon$ дуже вартісним (наприклад, вартість нематеріальних активів компанії «Кока-Кола» становить 96\% ринкової вартості компанії. Загальновідомо, що для цієї компанії ділова репутація понад усе. В IBM така частка становить $83 \%$. За даними аудиторської компанії "Ernst \& Young", у структурі власності найбільших світових корпорацій (Nike) нематеріальні активи становлять понад половину загальної вартості компанії, це явище має тенденцію до поширення) $)^{29}$. Бедвіл має місце, коли під час відчуження підприємства різниця між ціною угоди і вартістю активів є від'ємною. Бедвіл - явище виключно негативне для бізнесу, воно свідчить про неможливість управлінців зробити суб'єкт господарювання дохідним.

Розглянемо наступний актив, який є предметом незаконного збагачення, криптовалюту. Актуальним залишається питання, чи вважати криптовалюту одним із видів нематеріальних активів, чи це категорія електронних грошей. Термін «криптовалюта» трактується науковцями по-різному. Е.Ю. Молчанова та Ю.М. Солодковський зазначають, що криптовалюта - це цифрова фідуціарна валюта, де вільний режим, що плаває, є підставною для встановлення валютного курсу, наслідком попиту та пропозиції на валютному ринку із цілковитою відсутністю контролю 3 боку центробанків ${ }^{30}$. В.В. Закоржевський під криптовалютою розуміє систему розрахунків, засновану на децентралізованому зберіганні інформації стану рахунків та транзакцій, застосування їхніх криптографічних алгоритмів для забезпечення цілісності ${ }^{31}$. С.О. Галушка й О.Д. Пакон криптовалютою вважають цифрову систему платежів та грошових переказів, засновану на новітніх технологіях за принципами криптографії з метою функціонування як безпечної, анонімної, децентралізованої, стабільної віртуальної валюти ${ }^{32}$. На нашу думку, під криптовалютою варто розуміти цифрові нематеріальні активи, які являють собою систему розрахунків із постійно змінною вартістю, мають переважно анонімний характер та відсутність контролю зі сторони центробанків. Серед відомих криптовалют виокремлюють: Bitcoin, Ethereum, Dash, Ripple, Monero, Litecoin, Augur, MaidSafeCoin тощо. Найпоширенішою i найдорожчою криптовалютою $\epsilon$ біткоїн (Bitcoin). Bitcoin - це перша криптовалюта, яка була створена у 2008 р. На 2020 р. ціна

\footnotetext{
${ }^{29}$ Кришевич О.В. Гудвіл як одна із складових неправомірної вигоди. Актуальні проблеми кримінального права : тези доповідей Міжвузівської науково-теоретичної конференції, м. Київ, 2016 р. Київ : Нац. акад. внутр. справ, 2016. С. 80.

${ }^{30}$ Молчанова Е.Ю., Солодковський Ю.М. Глобальна сервісна природа сучасних криптовалют. 2014. С. 64.

31 Закоржевский В.В. Криптовалюты - обзор, принцип работы, текущее использование, правовое регулирование (Лаборатория Касперского, Москва, Россия). Глобальные рынки и финансовый инжиниринг. 2016. T. 3. № 4. C. 284.

${ }^{32}$ Галушка Є.О., Пакон О.Д Сутність криптовалют та перспективи їх розвитку. Молодий вчений. 2017. № 4 (44). $637 \mathrm{c}$.
} 
одного біткоїна становить приблизно 13000 доларів. Використовувати Bitcoin можна для обміну на товари або послуги за допомогою платформи «блок-чейн». Обмін криптовалют на класичні валюти здійснюється через онлайн-сервіс обміну цифрових валют, інші платіжні системи або обмінні пункти. В Україні немає нормативно-правового акта, який би регулював питання криптовалюти. У листопаді 2016 р. Національний Банк України заборонив обіг біткоїну на території України, пославшись на можливість його використання терористами та загрозу відмивання грошей за його допомогою. Усі риски за використання в розрахунках «віртуальної валюти / криптовалюти» несе учасник розрахунків. Національний банк України як регулятор не несе відповідальності за можливі ризики і втрати, пов'язані з використанням «віртуальної валюти / криптовалюти». 6 жовтня 2017 р. Верховна Рада України зареєструвала проєкт закону України «Про обіг криптовалюти в Україні», але 29 серпня 2019 р. його відхилено. У таких країнах, як Алжир, В'єтнам, Індонезія, Марокко, криптовалюта заборонена. У Японії, США, Канаді, Данії, Чехії, Німеччині криптовалюта легалізована та має офіційний характер. Штат Каліфорнія першим 3 усіх дозволив використати криптовалюту, ухвалив Assembly Bill $129^{33}$. Цей Закон дозволяє будь-якій компанії, асоціації або фізичній особі брати участь в обігу грошей, відмінних від законних платіжних систем. На нашу думку, не введення криптовалюти в Україні на офіційний рівень пов'язано 3 можливим виникненням проблем. Першою $є$ оподаткування криптовалюти, яка полягає в тому, здійснення криптовалютних операцій не зобов'язує суб'єкта вносити податок на додану вартість. Основною проблемою $є$ можливість зростання вчиненням корупційних правопорушень, оскільки довести отримання суб’єктом криптовалюти на законодавчому рівні неможливо.

\section{3. Обсяг зменшення фінансових зобов'язань, а також роботи} чи послуги, надані особі, уповноваженій на виконання функцій держави або місцевого самоврядування, як предмет незаконного збагачення

Термін «обсяг зменшення фінансового зобов'язання» був доданий до активів, що є предметом незаконного збагачення, разом із новою ст. 368-5 КК. Попередньо відповідальність за незаконне збагачення наставала за ст. 368-2 КК (визнано такою, що не відповідає Конституції України (є неконституційною), згідно з рішенням Конституційного Суду № 1-p/2019 від 26 лютого 2019 р.)), поняття «обсяг зменшення фінансового зобов'язання〉 не вживалося. Відповідно до ст. 368-2 КК, незаконне збагачення набуття особою, уповноваженою на виконання функцій держави або

\footnotetext{
33 Assembly Bill 129 : нормативний документ. P. 2. URL: http://www.leginfo.ca.gov/pub/13-14/bill/asm/ ab-0101-0150/ab-129-cfa-20140128-174724-asm-floor.html.
} 
місцевого самоврядування, у власність активів у значному розмірі, законність підстав для набуття яких не підтверджено доказами, а також передача нею таких активів будь-якій іншій особі. Під активами у значному розмірі в цій статті розумілися грошові кошти або інше майно, а також доходи від них, якщо їхній розмір (вартість) перевищує одну тисячу неоподатковуваних мінімумів доходів громадян ${ }^{34}$. Тобто попередня норма мала звужений характер та не розкривала повною мірою активи, які $\epsilon$ предметом незаконного збагачення. Відповідно до п. 1.4 Порядку реєстрації та обліку бюджетних зобов'язань розпорядників бюджетних коштів та одержувачів бюджетних коштів в органах Державної казначейської служби України, затвердженого наказом Міністерства фінансів України від 2 березня 2012 р. № 309, фінансове зобов’язання - будь-яке придбання товару, послуги чи виконання інших аналогічних операцій, здійснених розпорядником або одержувачем бюджетних коштів протягом бюджетного періоду з порушенням норм, установлених Бюджетним кодексом України, Законом «Про Державний бюджет України» та рішенням «Про місцевий бюджет» ${ }^{35}$. Відповідно до п. 9 ст. 46 Закону України «Про запобігання корупції», фінансові зобов'язання суб'єкта декларування або членів його сім’і - отримані кредити, позики, зобов'язання за договорами лізингу, розмір сплачених коштів у рахунок основної суми позики (кредиту) та процентів за позикою (кредитом), залишок позики (кредиту) станом на кінець звітного періоду, зобов'язання за договорами страхування та недержавного пенсійного забезпечення. Відомості щодо фінансових зобов'язань включають дані про вид зобов'язання, його розмір, валюту зобов'язання, інформацію про особу, стосовно якої виникли такі зобов'язання, відповідно до п. 1 ч. 1 ст. 46 Закону України «Про запобігання корупції», або найменування відповідної юридичної особи із зазначенням коду Єдиного державного реєстру юридичних осіб та фізичних осіб підприємців, та дату виникнення зобов'язання. Такі відомості зазначаються лише в разі, якщо розмір зобов'язання перевищує 50 прожиткових мінімумів, установлених для працездатних осіб на 1 січня звітного року ${ }^{36}$.

Роботи чи послуги, надані особі, уповноваженій на виконання функцій держави або місцевого самоврядування, як складова частина активів предмета незаконного збагачення мають свою специфіку. Вітчизняні та

\footnotetext{
${ }^{34}$ Кримінальний кодекс України : Закон від 5 квітня 2001 р. № 2341-III. URL: https://zakon.rada.gov.ua/ laws/show/2341-14.

${ }^{35}$ Про затвердження Порядку реєстрації та обліку бюджетних зобов’язань розпорядників бюджетних коштів та одержувачів бюджетних коштів в органах Державної казначейської служби України : наказ Міністерства фінансів України від 2 березня 2012 р. № 309, документ z0419-12. URL: https://zakon.rada.gov.ua/laws/show/z0419-12\#Text.

${ }^{36}$ Про запобігання корупції : Закон України» від 14 жовтня 2014 р. № 1700-VII. URL: https://zakon.rada.gov.ua/laws/show/1700-18\#Text.
} 
закордонні вчені трактують визначають категорії «послуги» по-різному. На думку В.В. Приходько, послуги - це корисний результат дії (діяльності), що полягає в корисному ефекті, який задовольняє потреби людини ${ }^{37}$. C.I. Чаусовська вважає, що послуга - це дія, яка приносить користь, допомогу іншому, сприяє досягненню поставленої мети та за допомогою засобів для досягнення цієї мети ${ }^{38}$. Законодавче визначення наведене в п. 17 ст. 1 Закону України «Про захист прав споживачів», де зазначено, що послуга - діяльність виконавця з надання (передачі) споживачеві певного визначеного договором матеріального чи нематеріального блага, що здійснюється за індивідуальним замовленням споживача для задоволення його особистих потреб ${ }^{39}$. Залежно від сфери надання послуги можна поділити на: соціальні, адміністративні та цивільно-правові. Відповідно до п. 17 Закону України «Про соціальні послуги», соціальні послуги - дії, спрямовані на профілактику складних життєвих обставин, подолання таких обставин або мінімізацію їхніх негативних наслідків для осіб/сімей, які в них перебувають. Особі/сім’і можуть надаватися одна або водночас декілька соціальних послуг. Порядок організації надання соціальних послуг затверджується Кабінетом Міністрів України ${ }^{40}$. С.М. Попова та Л.М. Попова вказують на те, що надання соціальних послуг грунтується на таких принципах: адресності й індивідуального підходу; доступності та відкритості; добровільності вибору отримання чи відмови від надання соціальних послуг; гуманності; комплексності; максимальної ефективності використання бюджетних та позабюджетних коштів суб'єктами, що надають соціальні послуги; законності; соціальної справедливості ${ }^{41}$. Соціальні-послуги бувають: соціально-побутові, соціально-педагогічні, соціально-медичні, соціальноекономічні, юридичні послуги, послуги із працевлаштування, інформаційні послуги. Відповідно до ст. 1 Закону України «Про адміністративні послуги», адміністративна послуга - результат здійснення владних повноважень суб'єктом надання адміністративних послуг за заявою фізичної або юридичної особи, спрямований на набуття, зміну чи припинення прав та/або обов'язків такої особи відповідно до закону ${ }^{42}$. Адміністративні послуги класифікують залежно від суб'єкта, що може їх надавати: державні, які

\footnotetext{
${ }^{37}$ Приходько В.В. Послуга як правова категорія та характеризуючи ознака договору розшуку. Підприємництво, господарство і право. 2006. С. 79.

${ }_{38}$ Чаусовська С.І. Поняття публічних послуг та їх класифікація. Держава та регіони. 2017. С. 103.

${ }^{39}$ Про захист прав споживачів : Закон України від 12 травня 1991 p. № 1023-XII. URL: https://zakon.rada.gov.ua/laws/show/1023-12\#Text.

${ }^{40}$ Про соціальні послуги : Закон України від 17 січня 2019 р. № 2671-VIII. URL: https://zakon.rada.gov.ua/laws/show/2671-19\#Text.

${ }_{41}$ Попова С.М., Попова Л.М. Особливості надання соціальних послуг в Україні. 2017. С. 29.

42 Про адміністративні послуги : Закон України від 6 вересня 2012 р. № 5203-VI. URL: https://zakon.rada.gov.ua/laws/show/5203-17\#Text.
} 
надаються органами державної влади та державними підприємствами, установами, організаціями, а також органами місцевого самоврядування в порядку виконання делегованих повноважень державним коштом, та муніципальні, які надаються органами місцевого самоврядування, а також органами виконавчої влади та підприємствами, установами, організаціями в порядку виконання делегованих органами місцевого самоврядування повноважень за коштом місцевого бюджету. Другим критерієм класифікації адміністративних послуг $\epsilon$ їх поділ залежно від оплатності, згідно 3 яким адміністративні послуги бувають оплатні та безоплатні. За сферою дії послуги можуть бути цивільно-правовими, які виникають переважно під час вирішення та регулювання цивільно-правових відносин. У ст. 177 Цивільного кодексу України передбачено, що послуга є об’єктом цивільного права ${ }^{43}$. Питання послуг як одного зі складників предмета складу кримінального правопорушення розглядала О.В. Кришевич. Послуги, пільги, переваги, які не мають матеріального змісту (похвальна характеристика чи виступ у пресі, надання престижної роботи тощо), не можуть визнаватися предметом неправомірної вигоди. Одержання такого характеру послуг, пільг чи переваг може розцінюватися як інша (некорислива) зацікавленість у разі зловживання владою чи службовим становищем i, за наявності підстав, кваліфікуватися за відповідною частиною ст. 364 КК України ${ }^{44}$.

Проаналізуємо поняття «роботи, які надані особі, уповноваженій на виконання функцій держави або місцевого самоврядування», як складову частину предмета незаконного збагачення. Поняття «роботи» та «послуги» за своїм змістом мають спільні риси. У ст. 837 Цивільного кодексу України передбачено, що за договором підряду одна сторона (підрядник) зобов'язується на свій ризик виконати певну роботу за завданням другої сторони (замовника), а замовник зобов'язується прийняти й оплатити виконану роботу. Послугами, як ми вже з'ясували, є дії, унаслідок виконання яких задовольняються суспільні потреби в окремих сферах діяльності.

\section{ВИСНОВКИ}

Проаналізовано предмет складу кримінального правопорушення незаконного збагачення, визначено аспекти, які в подальшому потребують удосконалення. У першому розділі розглянули поняття «грошові кошти» як предмет незаконного збагачення, встановили відсутність уніфікації зазначеного поняття та тлумачення його по-різному в нормативно-правових

\footnotetext{
${ }^{43}$ Цивільний кодекс України : Закон від 16 січня 2003 p. № 435-IV. URL: https://zakon.rada.gov.ua/laws/show/435-15.

${ }^{44}$ Кришевич О.В. Кримінальна відповідальність за хабарництво та відмежування його від шахрайства. Боротьба з організованою злочинністю і корупиією : теорія і практика. 2012. С. 117.
} 
актах. 3'ясували, що грошові кошти можуть бути у вигляді монет, паперових грошей, електронних грошей, кредитних грошей та валютних цінностей. Нами розглянуто кожен із зазначених видів. Під час розгляду електронних грошей здійснено порівняльну характеристику з готівковими, з'ясовано переваги та недоліки.

У другому розділі розглянуто поняття «інше майно» як складову частину активів незаконного збагачення, установлено, що вдалим є визначення, яке міститься в Конвенція Організації Об'єднаних Націй проти корупції. Майновими правами визнаються будь-які права, пов'язані 3 майном, відмінні від права власності, зокрема і права, які є складовими частинами права власності, а також інші специфічні права та права вимоги. Проведено класифікацію активів та досліджено їхні складові частини. Особливу увагу приділено поняттю «криптовалюта», установлено, що криптовалюту варто відносити до нематеріальних активів, сформульовано визначення. На нашу думку, під криптовалютою треба розуміти цифрові нематеріальні активи, які являють собою систему розрахунків із постійно змінною вартістю, мають переважно анонімний характер та відсутність контролю з боку центробанків.

У третьому розділі встановлено обсяг зменшення фінансових зобов'язань 3 урахуванням положень Закону України «Про запобігання корупції», розглянуто особливості понять «роботи» та «послуги», визначено їхні відмінності.

\section{АНОТАЦІЯ}

Одним із видів корупційних кримінальних правопорушень $є$ незаконне збагачення. Предмет незаконного збагачення належить до предметів кримінальних правопорушень у сфері службової діяльності та професійної діяльності, пов'язаної з наданням публічних послуг. У науковій статті розглянуто предмет складу кримінального правопорушення незаконного збагачення і встановлено, що предметом незаконного збагачення $є$ активи, до яких відносять грошові кошти, інше майно, майнові права, нематеріальні активи, криптовалюту, обсяг зменшення фінансових зобов'язань, а також роботи чи послуги, надані особі, уповноваженій на виконання функцій держави або місцевого самоврядування. Проаналізовано кожен із вищезазначених складників предмета незаконного збагачення (кошти, інше майно, майнові права, нематеріальні активи, криптовалюта, обсяг зменшення фінансових зобов'язань, а також роботи чи послуги), 3 використанням національного та міжнародного законодавства. Отже, грошові кошти можуть бути у вигляді монет, паперових грошей, електронних грошей, кредитних грошей та валютних цінностей, нами розглянуто кожен із зазначених видів. 
Під час розгляду електронних грошей здійснено порівняльну характеристику 3 готівковими, визначено переваги та недоліки. Майновими правами визнаються будь-які права, пов'язані з майном, відмінні від права власності, зокрема і права, які є складовими частинами права власності, а також інші специфічні права та права вимоги. Проведено класифікацію активів, досліджено їхні складові частини. Особливу увагу приділено поняттю «криптовалюта». Визначено, що криптовалюту варто відносити до нематеріальних активів, сформульовано визначення. Криптовалюта - це цифрові нематеріальні активи, які являють собою систему розрахунків із постійно змінною вартістю, мають переважно анонімний характер, відсутність контролю з боку центробанків.

\section{ЛІТЕРАТУРА}

1. Бондаренко О.С. Предмет злочинів у сфері службової діяльності та професійної діяльності, пов'язаної з наданням публічних послуг. Київ, 2016. С. 90.

2. Галушка Є.О., Пакон О.Д Сутність криптовалют та перспективи їх розвитку. Молодий вчений. 2017. № 4 (44). С. 637.

3. Господарський кодекс України : Закон від 16 січня 2003 р. № 436-IV. URL: https://zakon.rada.gov.ua/laws/show/436-15\#Text.

4. Срмолаєва М.В., Черненко К.В., Гафіяк А.М. Облік грошових коштів та застосування інформаційних облікових технологій. 2013. 216 с.

5. Про адміністративні послуги : Закон України від 6 вересня 2012 p. № 5203-VI. URL: https://zakon.rada.gov.ua/laws/show/5203-17\#Text.

6. Про банки і банківську діяльність : Закон України від 7 грудня 2000 p. № 2121-III. URL: https://zakon.rada.gov.ua/laws/show/2121-14\#Text.

7. Про валюту і валютні цінності : Закон України від 21 червня 2018 р. № 2473-VIII. URL: https://zakon.rada.gov.ua/laws/show/2473-19\#Text.

8. Про державне регулювання видобутку, виробництва і використання дорогоцінних металів і дорогоцінного каміння та контроль за операціями 3 ними : Закон України від 18 листопада 1997 р. № 637/97-BP. URL: https://zakon.rada.gov.ua/laws/show/637/97-\%D0\%B2\%D1\%80\#Text.

9. Про захист прав споживачів : Закон України від 12 травня 1991 р. № 1023-XII. URL: https://zakon.rada.gov.ua/laws/show/1023-12\#Text.

10. Про запобігання корупції : Закон України від 14 жовтня 2014 р. № 1700-VII. URL: https://zakon.rada.gov.ua/laws/show/1700-18\#Text.

11. Про оцінку майна, майнових прав та професійну оціночну діяльність в Україні : Закон України від 5 квітня 2001 p. № 2346-III. URL: https://zakon.rada.gov.ua/laws/show/2658-14\#Text. 
12. Про платіжні системи та переказ коштів в Україні : Закон України від 12 червня 2001 р. № 2658-III. URL: https://zakon.rada.gov.ua/laws/show/ 2658-14\#Text.

13. Про соціальні послуги : Закон України від 17 січня 2019 р. № 2671-VIII. URL: https://zakon.rada.gov.ua/laws/show/2671-19\#Text.

14. Про цінні папери та фондовий ринок : Закон України від 23 лютого 2006 p. № 3480-IV. URL: https://zakon.rada.gov.ua/laws/show/3480-15\#Text.

15. Закоржевский В.В. Криптовалюты - обзор, принцип работы, текущее использование, правовое регулирование (Лаборатория Касперского, Москва, Россия). Глобальные рынки и финансовый инжсииринг. 2016. Т. 3. № 4. C. 284.

16. Коваленко Д. І. Гроші та кредит : теорія і практика : навчальний посібник. Київ, 2011. С. 344.

17. Конвенція Організації Об’єднаних Націй проти корупції від 31 жовтня 2003 р., документ 995-c16. URL: https://zakon.rada.gov.ua/laws/show/995_ c16\#Text.

18. Конституція України : Закон від 28 червня 1996 р. № 254к/96-BP. URL: https://zakon.rada.gov.ua/laws/show/254\%D0\%BA/96-\%D0\%B2\%D1\%80\#Text.

19. Кримінальний кодекс України : Закон від 5 квітня 2001 р. № 2341-III. URL: https://zakon.rada.gov.ua/laws/show/2341-14.

20. Кришевич О.В. Гудвіл як одна із складових неправомірної вигоди. Актуальні проблеми кримінального права : тези доповідей Міжвузівської науково-теоретичної конференції, м. Київ, 2016 р. Київ : Нац. акад. внутр. справ, 2016. С. 80.

21. Кришевич О.В. Кримінальна відповідальність за хабарництво та відмежування його від шахрайства. Боротьба з організованою злочинністю і корупиією : теорія і практика. 2012. С. 117.

22. Мага К.І. Поняття «грошові кошти та їх еквіваленти» i його відображення в обліково-аналітичній системі підприємства. 2018. С. 108.

23. Міжнародний стандарт бухгалтерського обліку 7 (МСБО 7). Звіт про рух грошових коштів від 1 січня 2012 р., документ 929-019. URL: https://zakon.rada.gov.ua/laws/show/929_019\#Text.

24. Міжнародний стандарт бухгалтерського обліку 38 (МСБО 38) «Нематеріальні активи» від 1 січня 2012 р., документ № 929-050. URL: https://zakon.rada.gov.ua/laws/show/929_050.

25. Молчанова Е.Ю., Солодковський Ю.М. Глобальна сервісна природа сучасних криптовалют. 2014. С. 64.

26. Assembly Bill 129 : нормативний документ. P. 2. URL: http://www.leginfo.ca.gov/pub/13-14/bill/asm/ab_0101-0150/ab_129_cfa_ 20140128_174724_asm_floor.html. 
27. Податковий кодекс України : Закон від 2 грудня 2010 р. № 2755-VI ; ред. станом на 21 жовтня 2020 р. Відомості Верховної Ради Украйни. 2011. № № 13-17. Ст. 112. URL: https://zakon.rada.gov.ua/laws/show/2755-17.

28. Попова С.М., Попова Л.М. Особливості надання соціальних послуг в Україні. 2017. С. 29.

29. Приходько В.В. Послуга як правова категорія та характеризуючи ознака договору розшуку. Підприємниитво, господарство і право. 2006. C. 79 .

30. Про затвердження Національного положення (стандарту) бухгалтерського обліку в державному секторі 101 «Подання фінансової звітності» : наказ Міністерства фінансів України від 28 грудня 2009 р. № 1541, документ z0103-10. URL: https://zakon.rada.gov.ua/laws/show/ z0103-10\#Text.

31. Про затвердження Положення про ведення касових операцій у національній валюті в Україні : постанова правління Національного банку України від 29 грудня 2017 р. № 148, документ v0148500-17. URL: https://zakon.rada.gov.ua/laws/show/v0148500-17\#Text.

32. Про затвердження Правил визначення платіжних ознак та обміну банкнот, розмінних та обігових монет національної валюти України : постанова правління Національного банку України від 3 грудня 2018 р. № 134, документ v0134500-18. URL: https://zakon.rada.gov.ua/laws/ show/v0134500-18\#Text.

33. Про затвердження Положення про порядок здійснення операцій з чеками в іноземній валюті на території України : постанова правління Національного банку України від 29 грудня 2000 р. № 520, документ z0152-01. URL: https://zakon.rada.gov.ua/laws/show/z0152-01\#Text.

34. Про Національне положення (стандарт) бухгалтерського обліку в державному секторі 122 «Нематеріальні активи» : наказ Міністерства фінансів України від 12 жовтня 2010 р. № 1202. URL: https://zakon.rada.gov.ua/ laws/show/z1018-10\#Text.

35. Про затвердження Порядку реєстрації та обліку бюджетних зобов'язань розпорядників бюджетних коштів та одержувачів бюджетних коштів в органах Державної казначейської служби України : наказ Міністерства фінансів України від 2 березня 2012 р. № 309, документ z0419-12. URL: https://zakon.rada.gov.ua/laws/show/z0419-12\#Text.

36. Рябіна Л.М. Функції сучасних грошей та їх особливості. Вісник соиіально-економічних досліджень. 2011. С. 99.

37. Чаусовська С.I. Поняття публічних послуг та їх класифікація. Держава та регіони. 2017. С.103. 
38. Чернецька С.А. Аналіз активів підприємств. Облік, аналіз, аудит. 2013. C. 332.

39. Цивільний кодекс України : Закон від 16 січня 2003 р. № 435-IV. URL : https://zakon.rada.gov.ua/laws/show/435-15.

Information about the authors: Kryshevych O. V., Ph. D.,

Professor at the Criminal Law Department National Academy of Internal Affairs 1, Solomianska square, Kyiv, 03035, Ukraine

Bezghynskyi B. G., Postgraduate Student National Academy of Internal Affairs 1, Solomianska square, Kyiv, 03035, Ukraine 